\title{
THREE NEW RARELY COLLECTED OR ENDANGERED SPECIES OF ANNONACEAE FROM VENEZUELA
}

\author{
LARS W. CHATROU \& MICHAEL D. PIRIE \\ Nationaal Herbarium Nederland, Utrecht University branch, Heidelberglaan 2, \\ 3584 CS Utrecht, The Netherlands
}

\begin{abstract}
SUMMARY
Three new species of Annonaceae from Venezuela are described here: Cremastosperma venezuelanum Pirie, Klarobelia subglobosa Chatrou, and Pseudomalmea wingfieldii Chatrou. All three are represented by few collections (in comparison to those of other Neotropical species of Annonaceae). Klarobelia subglobosa and $P$. wingfieldii in particular are only known from a few individual specimens collected in areas vulnerable to habitat destruction. IUCN threat categories are assigned to these species.
\end{abstract}

Key words: Annonaceae, Cremastosperma, Klarobelia, Pseudomalmea, Neotropics, Venezuela, threatened/endemic species.

\section{INTRODUCTION}

Klarobelia, Pseudomalmea, and Cremastosperma are three Neotropical genera of the flowering plant family Annonaceae. Klarobelia and Pseudomalmea include a number of species originally assigned to the genus Malmea, as described by Fries in 1905. Of the 19 species originally described under Malmea, 12 were subsequently moved to three new genera described by Chatrou (1998) on the basis of leaf, inflorescence, and seed characters: Klarobelia (now including 12 recognised species), Mosannona (14), and Pseudomalmea (3). Two new species, one of Klarobelia (K. subglobosa) and one of Pseudomalmea ( $P$. wingfieldii), both endemic to Venezuela, are described here.

The genus Cremastosperma was also described by Fries (1930), and phylogenetic analyses using DNA sequence data suggest that its species comprise a monophyletic group (Pirie et al., in press). 29 species of Cremastosperma are currently recognised, although results of current systematic research suggest that the total number of distinguishable species may in fact exceed 30. A second endemic species for Venezuela, $C$. venezuelanum (the first being C. macrocarpum, described by Maas in Maas et al., 1986), is described here.

The number of collections available for the description of these new species was small in comparison to those known for many other Neotropical species of Annonaceae. Not all localities in the Neotropics are equally well collected or understood, and paucity of specimens does not necessarily reflect more than a lack of information with regards to the rarity or conservation status of particular taxa. However, our knowledge of both the threats present to the areas in which, in particular, Klarobelia subglobosa 
and Pseudomalmea wingfieldii are found, and of the sparse distribution of individuals of these taxa in these areas, leads us to conclude that these species may with some confidence be considered as threatened. For these species the specific nature of the threat is described, and appropriate IUCN threat categories (IUCN, 2001) are assigned.

\section{Cremastosperma venezuelanum Pirie, spec. nov. - Fig. 1; Map 1}

Lamina basi cordata (raro rotundata), venis secundariis basim versus sub angulo magno e costa exeuntibus, indumento ubique nullo distinctum. - Typus: Diaz \& Niño 231 (holo U; iso NY), Venezuela, Carababo, Autonomo Mora, Watershed of Morón river, 3 May 1991.

Tree 7-10 m tall; young twigs and petioles glabrous. Leaves: petioles $10-20 \mathrm{~mm}$ long, $3-4 \mathrm{~mm}$ diam.; lamina narrowly elliptic, $30-53$ by $9-15 \mathrm{~cm}$, index $3-3.6$, chartaceous to subcoriaceous, shiny, dark brown above, olive green/greyish/light to dark brown

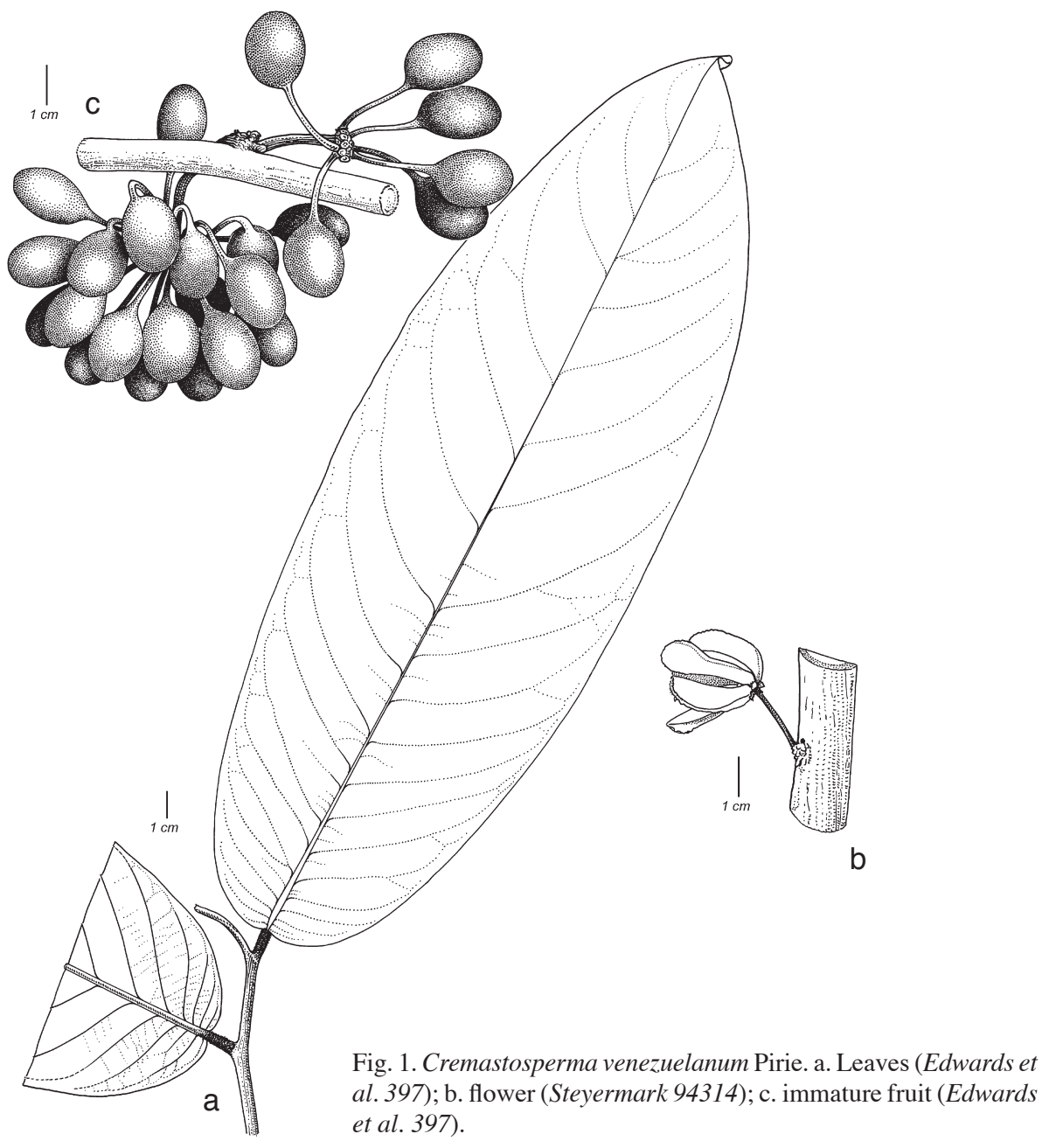


below, glabrous on both sides, base cordate (rarely rounded), apex obtuse to acute, primary vein raised over its entire length, $2.5-5 \mathrm{~mm}$ wide at the widest point, secondary veins $15-30$, intersecondary veins occasional, distance between from $12 \mathrm{~mm}$ at the base to $40 \mathrm{~mm}$ closer to the apex, angles with primary vein from $90^{\circ}$ at the base to $60-50^{\circ}$ closer to the apex, rarely branching, forming more or less indistinct loops, smallest distance between loops and margin $2-3 \mathrm{~mm}$; tertiary veins showing some reticulation. Inflorescence of single flowers clustered in groups of up to 6, produced from the main trunk or from leafless branches; short axillary shoot c. 2 by $1 \mathrm{~mm}$ (in flower), 3-5 by $1.5-3 \mathrm{~mm}$ (in fruit); pedicels c. 11 by $1 \mathrm{~mm}$ (in flower), 16-22 by $1.5-2 \mathrm{~mm}$ diam. at the base, 2-3 mm diam. at the apex (in fruit), glabrous; single lower bract, very broadly triangular, 0.5-1 mm long, obtuse, persistent, glabrous; upper bract attachment variable within central $80 \%$ of length, c. 1 by $1.5 \mathrm{~mm}$, depressed triangular, obtuse, glabrous; flower buds and flowers at anthesis not seen; flowers dark brown to black in sicco, all parts glabrous; sepals free, depressed triangular, reflexed, c. 1 by $1.5 \mathrm{~mm}$, acute to obtuse, persistent on less mature fruits; outer petals elliptic, c. 18 by $10 \mathrm{~mm}$, inner petals narrowly elliptic, c. 21 by $6 \mathrm{~mm}$; receptacle depressed ovoid; androecium c. $4 \mathrm{~mm}$ diam., stamens c. 60 , c. $1 \mathrm{~mm}$ long, connective rhombic, c. $0.4 \mathrm{~mm}$ wide; gynoecium c. $1.8 \mathrm{~mm}$ diam., carpels 30-40, 0.6-0.7 mm long. Monocarps 20-35, black in sicco, ellipsoid, asymmetrical, $17-20$ by $12-13 \mathrm{~mm}$, apicule strongly excentric, glabrous; stipes $15-22$ by $1.5-2 \mathrm{~mm}$, glabrous; fruiting receptacle depressed ovoid, 5-12 $\mathrm{mm}$ diameter. Seeds ellipsoid, orange-brown with many shallow pits, $15-17$ by $13-16 \mathrm{~mm}$, raphe raised, encircling seed longitudinally, rumination spiniform.

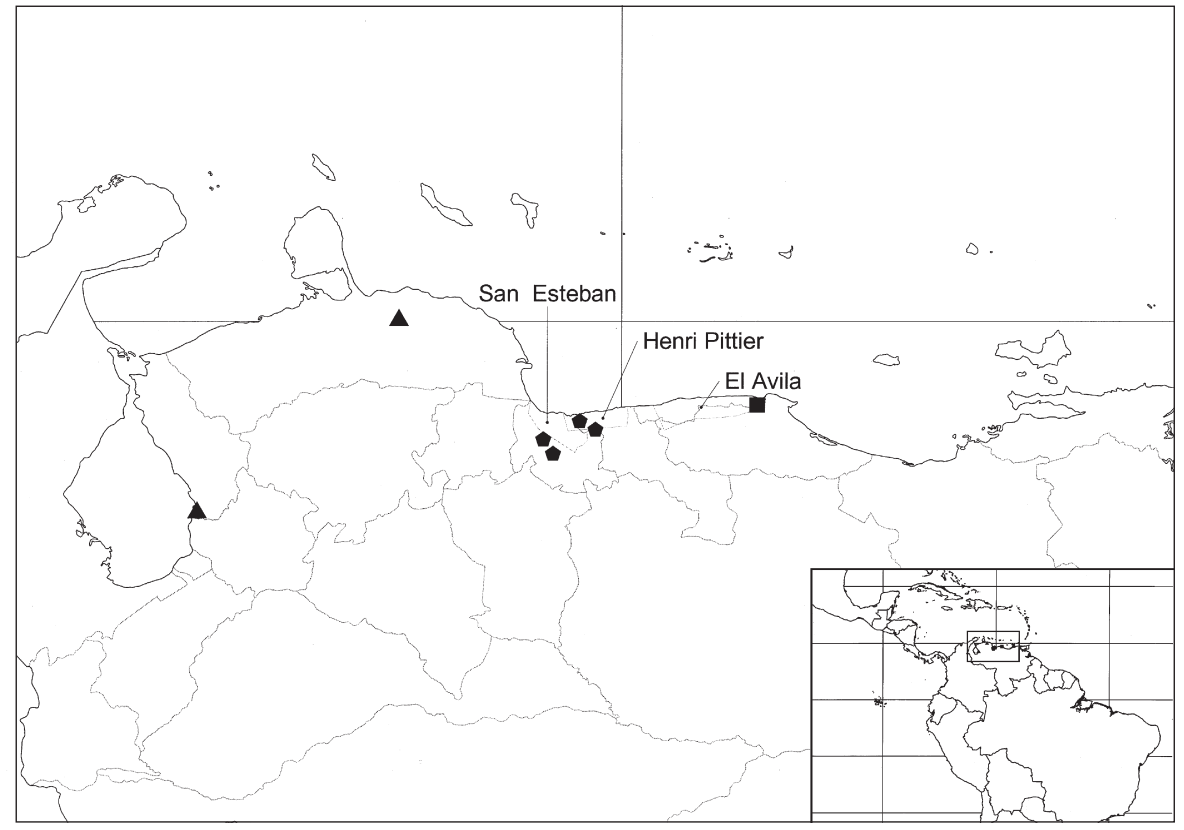

Map 1. Distribution of Cremastosperma venezuelanum Pirie (-), Klarobelia subglobosa Chatrou ( and Pseudomalmea wingfieldii Chatrou $(\mathbf{\Delta})$. Nearby national parks are indicated. 
Distribution - Only known from four collections from the states of Aragua and Carabobo in Venezuela.

Habitat \& Ecology - Growing in the understorey of primary, moist, evergreen forest at elevations between 350 and $1100 \mathrm{~m}$. Fruiting specimens have been collected in the months of April and May, one flowering specimen in August.

Note - Cremastosperma venezuelanum is best distinguished from other species of Cremastosperma by its distinctive acute to obtuse leaf apex (as opposed to acuminate in other species). The combination of its distinctive cordate (rarely rounded) leaf base, the large angles of the secondary with the primary veins near the base of the leaves and the lack of indument on any parts is also unique. Only one other species of Cremastosperma has been collected in Venezuela; C. macrocarpum Maas, which has larger monocarps with shorter, thicker stipes.

Paratypes:

VenezUela. Aragua: Henri Pittier National Park, 1 April 1990 (fr), Edwards et al. 397 (NY); National Park; Dos Riitos, 19 May 1943 (fr), Killip et al. 37752 (NY, S). Carababo: San Gián river, 5-6 km S of Borburata, 7 Aug. 1965 (fl), Steyermark 94314 (NY, US).

\section{Klarobelia subglobosa Chatrou, spec. nov. - Fig. 2a; Map 1}

A speciebus ceteris huius generis differt monocarpiis subglobosis - Typus: Meier \& Llamozas 3685 (holo U [2 sheets]; iso VEN), Venezuela, Distrito Federal, National Park 'El Avila', Fila Jabillar, alt. 500 m, 16-19 April 1993.

Tree of unknown height; young twigs and lower side of petioles, primary vein and basal part of lower side of leaf blade rather densely covered with brownish, appressed hairs $0.2-0.4 \mathrm{~mm}$ long. Petiole $4-6$ by $1-2 \mathrm{~mm}$. Lamina $6-10$ by $2.5-4.5 \mathrm{~cm}$, length/width ratio 2.2-2.8, chartaceous to subcoriaceous, (narrowly) elliptic, base shortly attenuate, apex acute (or gradually acuminate), olive-green to brown on both sides, shiny on both sides, glabrous above, secondary veins $6-8$ per side, distance between secondary veins $9-18 \mathrm{~mm}$, angles with primary vein $45-60^{\circ}$, loop-forming at acute to right angles, distance between loops and leaf margin 2-3 mm. Inflorescences on older branches (only observed in fruiting stage), short shoot $20-45$ by $3-4 \mathrm{~mm}$, sparsely covered with brownish, appressed hairs $0.2-0.4 \mathrm{~mm}$ long, leaves on short shoot 7 by $2.5 \mathrm{~cm}$, caducous, pedicels $17-19$ by $4 \mathrm{~mm}$ basally to 5-6 $\mathrm{mm}$ apically. Flowers unknown. Fruit of 10-12 monocarps, light brown in sicco, subglobose, $18-24$ by $16-21 \mathrm{~mm}$, glabrous, verrucose, stipes $30-46$ by $1-2.5 \mathrm{~mm}$, glabrous, verrucose, fruiting receptacle transversely ellipsoid, 9-13 mm diam., 6-7 mm high, glabrous. Seeds subglobose, $17-23$ by $15-20 \mathrm{~mm}$, reddish brown, shallowly transversely striate, raphe impressed, slightly sinuous.

Distribution - Only known from the type locality, in El Avila National Park, in the surroundings of Caracas, at an elevation of $500 \mathrm{~m}$.

Habitat \& Ecology - In semi-deciduous forest on the north-eastern side of the Venezuelan central coastal mountain range, of which the El Avila National Park is part.

Notes - Klarobelia subglobosa is only known from the type collection. Despite extensive explorations, reflected in Steyermark \& Huber (1978) and Meier (1998), 
only a single specimen of this new species has been collected. In Meier (1998), K. subglobosa has been listed as Malmea diclina. According to the label, the specimen has been collected from a fallen, dried tree.

Despite the poor material, K. subglobosa can easily be distinguished from other species in the genus by its subglobose monocarps. The species is most similar to K. stipitata, an endemic of the Osa Peninsula, Costa Rica, with which it shares the presence of non-reduced leaves on the short shoot subtending the inflorescence. The short shoot in all other species of Klarobelia is provided with bracts. Leaves of $K$. stipitata are 10.5-16.5 $\mathrm{cm}$ long and narrowly elliptic, whereas leaves of $K$. subglobosa are $6-10 \mathrm{~cm}$ long and usually elliptic. Furthermore, monocarps of $K$. stipitata are broadly ellipsoid, rarely subglobose, and typically dry black, instead of light brown as in K. subglobosa.
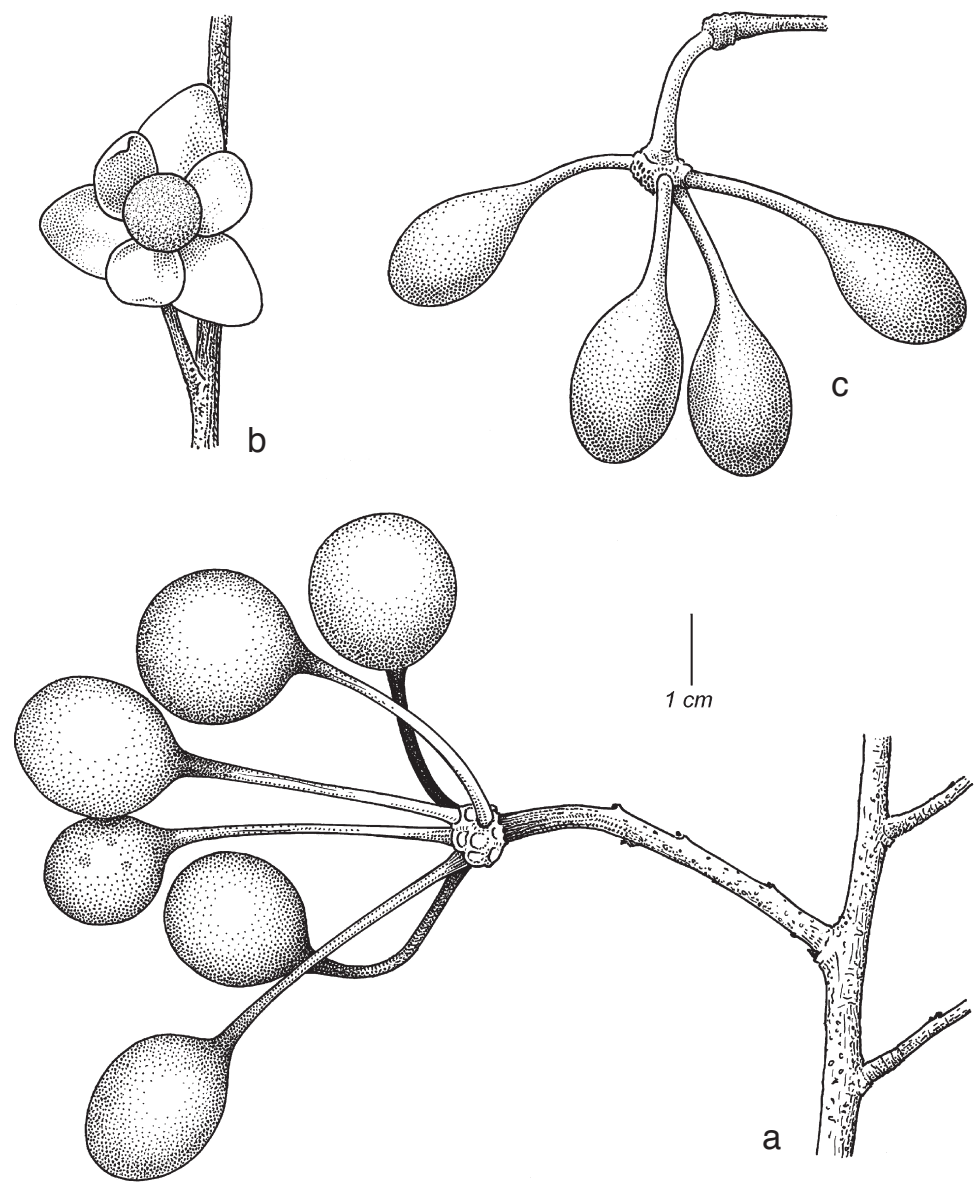

Fig. 2. a. Klarobelia subglobosa Chatrou. Immature fruit (Meier \& Llamozas 3685). - b, c. Pseudomalmea wingfieldii Chatrou. b. Flower before anthesis; c. immature fruit (Pendry \&Wingfield 1034). 
Conservation - El Avila is vulnerable: there is a risk that the various threats it faces will increasingly threaten its biodiversity (ParksWatch; www.parkswatch.org).

Assessing the conservation status of K. subglobosa, we judge this species to be critically endangered under the following criterion for this threat category (IUCN, 2001): Criterion D, population size estimated to number fewer than 50 mature individuals. Klarobelia subglobosa might classify as critically endangered under other IUCN criteria as well. However, as these criteria involve changes over time (e.g. of population size, area of occupancy, number of mature individuals), they are impossible to assess given the fact that only one herbarium specimen of this taxon has ever been collected.

\section{Pseudomalmea wingfieldii Chatrou, spec. nov. - Fig. 2b, c; Map 1}

A speciebus ceteris huius generis differt pedicello supra articulationem ebracteato, praeterea stipite breviore notabilis. - Typus: Pendry \& Wingfield 1034 (holo U [2 sheets]; iso E, VEN), Venezuela, Falcón, Los Tablones, 4 km downstream from Las Dos Bocas, alt. 100 m, 16 November 2000.

Tree to $15 \mathrm{~m}$ tall, bark smooth and dark grey. Young twigs and lower side of petioles and primary vein glabrous to sparsely covered with brownish, appressed hairs $0.1-0.2 \mathrm{~mm}$ long. Petiole $3-5$ by $1-2 \mathrm{~mm}$. Lamina $6-14$ by $2.5-5 \mathrm{~cm}$, length/width ratio 1.9-3.2, chartaceous, (narrowly) elliptic, sometimes (narrowly) obovate, often falcate, base cuneate to acute, rarely attenuate, apex gradually acuminate (or acute), olive-green and often shiny on both sides, glabrous above, glabrous to sparsely covered with brownish, appressed hairs $0.1-0.2 \mathrm{~mm}$ long below, secondary veins $6-10$ per side, distance between secondary veins $10-18 \mathrm{~mm}$, angles with primary vein $45-60^{\circ}$, rarely loop-forming and diminishing towards leaf margin, intersecondaries present, tertiary venation conspicuous and reticulate. Inflorescences rhipidiate, on leafy twigs or on older branches, single-flowered at any point in time; indument: short shoot, pedicels, and outer side of bracts rather densely covered with (yellowish) brown, (erect to) appressed hairs $0.2-0.4 \mathrm{~mm}$ long, less densely in fruiting stage; short shoot $2-8$ by $1.5-2 \mathrm{~mm}$, $3 \mathrm{~mm}$ diam. when fruiting, leaves on short shoot 5 by $3-3.5 \mathrm{~cm}$, caducous, bracts on short shoot 2 by $2 \mathrm{~mm}$, flowering pedicels $15-23$ by $1 \mathrm{~mm}$ basally to $1.5 \mathrm{~mm}$ apically, fruiting pedicels to 29 by $2 \mathrm{~mm}$ basally to $3 \mathrm{~mm}$ apically. Flowers bisexual, petals patent during most of flower development, inner three petals curving over floral centre before anthesis. Flower colour pale yellow at anthesis (in vivo), cinnamon (in sicco). Sepals free, transversely ovate, 2 by $3 \mathrm{~mm}$, ciliate, outer side densely covered with yellowish brown, appressed hairs $0.2 \mathrm{~mm}$ long, inner side glabrous. Petals obovate (to elliptic), fleshy and rigid. Outer petals $11-20$ by $7-14 \mathrm{~mm}$, on both sides densely covered with yellowish brown, appressed to erect, often curly, hairs $0.1 \mathrm{~mm}$. Inner petals $8-20$ by 6-15 mm, concave at base, outer side rather densely hairy (same hairs as outer petals), inner side glabrous to sparsely hairy, papillate. Stamens 100-150, 1.4-1.6 mm long, thecae $0.8-1 \mathrm{~mm}$ long, extrorse, prolonged connective discoid, papillose, glabrous. Carpels c. 200, ovaries 1-1.2 mm long, several-ribbed, totally covered with yellowish brown, appressed hairs $0.1-0.2 \mathrm{~mm}$, stigmas $0.3-0.5 \mathrm{~mm}$ long, papillose, densely covered with hairs $\leq 0.05 \mathrm{~mm}$ long. Flowering receptacle transverse elliptic, flat on top, 2-3 mm high, 5-6 mm diam., staminate portion glabrous, carpellate portion densely hairy. Fruit of 4-6 monocarps, red at maturity (in vivo), (reddish) brown in sicco, 
with red pulp at maturity (in vivo), ellipsoid, $21-35$ by $12-21 \mathrm{~mm}$, (sub)glabrous, verrucose, stipes 17-30 by 1-2 mm, (sub)glabrous, verrucose, fruiting receptacle transversely ellipsoid, 7-10 mm diam., 4-5 mm high, densely hairy. Seeds ellipsoid, $19-33$ by $10-19 \mathrm{~mm}$, reddish brown, shallowly transversely striate, raphe slightly raised, verrucose and rugose, $1 \mathrm{~mm}$ wide.

Distribution - Only known from two individuals: the tree from which Tejera s.n. was collected (the Venezuelan state of Zulia), and an individual from which all remaining collections were gathered (Wingfield, pers. comm.), in the state of Falcón, Venezuela. Elevation $100 \mathrm{~m}$.

Habitat \& Ecology - Semideciduous, riverine forest.

Notes - Of Pseudomalmea wingfieldii only bisexual flowers have been observed. The other two species of Pseudomalmea, P. boyacana and P. diclina, are androdioecious. Androdioecy in Annonaceae is correlated with a higher number of carpels compared to the number of stamens in bisexual flowers, e.g. in Klarobelia, Pseudomalmea (Chatrou, 1998), Anonidium (Le Thomas, 1969), and Greenwayodendron (Verdcourt, 1969). A carpel-stamen ratio comparable to Pseudomalmea boyacana and P. diclina is observed in $P$. wingfieldii. It is therefore expected that the latter should also be androdioecious.

Bracts (in Pendry \& Wingfield 1034) as well as non-reduced leaves (in Wingfield 8668,15289 ) have been found on the short shoot subtending the inflorescence in $P$. wingfieldii. The occurrence of bracts on the short shoot is a feature not observed in the remaining two species of Pseudomalmea. In Wingfield 15289 a lateral inflorescence, only observed in a very young stage, originates from the axil of a non-reduced leaf. The occurrence of such a paracladium has not been observed before in Pseudomalmea, but is known e.g. from species in the Neotropical genus Unonopsis (L. Westra, pers. comm.). The absence of a bract on the part of pedicel above the articulation is a remarkable feature of $P$. wingfieldii. Chatrou (1998) used this as one of the characters to distinguish Pseudomalmea from Klarobelia. In every other respect, however, $P$. wingfieldii evidently belongs to Pseudomalmea, most notably because of the clear, reticulate venation, the inflorescences on a short, axillary shoot, the spreading of the petals during flower development, and the seeds with lamellate, four-parted ruminations and a raised, straight raphe.

Etymology - Pseudomalmea wingfieldii is named after Dr. Robert Wingfield, founder and curator of herbarium CORO (Instituto Tecnólogico Alfonso Gamero, Coro), the herbarium for the Venezuelan state of Falcón.

Conservation - Only two individuals of $P$. wingfieldii have ever been encountered. The individual in the state of Falcón grows by the river Ricoa, and is under immediate threat due to planned infrastructural works (Wingfield, pers. comm.). Under the same IUCN (2001) criterion as applied to Klarobelia subglobosa, we assess $P$. wingfieldii to be critically endangered. Similar to K. subglobosa, more criteria for critically endangered species might apply to $P$. wingfieldii, but this cannot be evaluated due to the limited number of collections and known individuals.

Paratypes:

VENEZUELA. Zulia: Dept. of Bolívar, La Barua, hacienda La Concha, Tejera s.n. (VEN). Falcón: Río Ricoa, 4 km E of Las Dos Bocas, 35 km ESE of Coro, 100 m, Wingfield 7940 (CORO, U), ibidem, Wingfield 8668 (CORO, U), ibidem, Wingfield \& Hernández 15289 (CORO, U). 


\section{ACKNOWLEDGEMENTS}

The authors thank Robert Wingfield for sharing his field observations on Pseudomalmea wingfieldii, and above all for his dedication to the conservation of this rare species, Luis Lemus for making available photographs of living flowers and fruits, Colin Pendry for photographs (from which Fig. $2 \mathrm{~b}$ and $\mathrm{c}$ are drawn) and information on the type specimen of $P$. wingfieldii, and Winfried Meier for information about the Klarobelia subglobosa specimen. The herbarium curators of NY, S, U, US, and VEN are acknowledged for the loan of collections. Craig Hilton-Taylor is acknowledged for providing information on the IUCN Red List of Threatened Species. Maps were produced using ESRI data made available by the New York Botanical Garden's 'Digital Basemap of the Americas'. Hendrik Rypkema's art work, and Lubbert Westra's translation of the diagnoses are gratefully acknowledged.

\section{REFERENCES}

Chatrou, L.W. 1998. Changing Genera: Systematic studies in Neotropical and West African Annonaceae. PhD Thesis. Utrecht University, the Netherlands.

Fries, R.E. 1905. Studien in der Riedel'schen Anonaceen-Sammlung. Ark. Bot. 5, 4: 1-24.

Fries, R.E. 1930. Revision der Arten einiger Anonaceen-Gattungen I. Acta Horti Berg. 10: 1-128.

IUCN. 2001. The IUCN red list of threatened species, 2001 categories and criteria, version 3.1. IUCN, Gland, Switzerland.

Le Thomas, A. 1969. Annonacées. In: A. Aubréville (ed.), Flore du Gabon 16. Muséum National d'Histoire Naturelle, Paris.

Maas, P.J.M., E.C.H. van Heusden, J. Koek-Noorman, A.K. van Setten \& L.Y.Th. Westra. 1986. Studies in Annonaceae. VII. New species from the Neotropics and miscellaneous notes. Proc. Kon. Ned. Akad. Wetensch., Ser. C 89: 249-278.

Meier, W. 1998. Flora und Vegetation des Avila-National parks (Venezuela/Küstenkordillere). Dissertationes Botanicae 296. Cramer, Berlin/Stuttgart.

Pirie, M.D., L.W. Chatrou, R.H.J. Erkens, J.W. Maas, T. van der Niet, J.B. Mols \& J.E. Richardson. In press. Phylogeny reconstruction and molecular dating in four Neotropical genera of Annonaceae: the effect of taxon sampling in age estimations. In: F.T. Bakker, L.W. Chatrou, B. Gravendeel \& P.B. Pelser (eds.), Plant species-level systematics: new perspectives on pattern and process. Regnum Veg. 143. Koeltz Scientific Books \& IAPT, Vienna.

Steyermark, J. A. \& O. Huber. 1978. Flora del Avila. INCAFO, Madrid.

Verdcourt, B. 1969. The status of the genus Polyalthia Blume (Annonaceae) in Africa. Adansonia, n.s. 9: 87-94. 